\title{
Manufacturing Strategies for the Ecosystem-Based Manufacturing System in the Context of 3D Printing
}

\author{
Ke Rong ${ }^{\mathrm{a}}$, Yong Lin ${ }^{\mathrm{b} *}$, Jiang $\mathrm{Yu}^{\mathrm{c}}$ and Yue Zhang ${ }^{\mathrm{d}}$ \\ ${ }^{a}$ School of Social Science, Tsinghua University, Beijing, China \\ ${ }^{b}$ School of Business, University of Greenwich, London, UK \\ ${ }^{c, d}$ Institute of Policy and Management, Chinese Academy of Sciences, Beijing, China
}

*Corresponding author: Dr Yong Lin

30 Park Row, School of Business, University of Greenwich, London, UK, SE10 9LS

Email: $\underline{\text { Y.Lin@gre.ac.uk }}$

Tel: 00442083319114

Dr Ke Rong is an associate professor at the School of Social Science of Tsinghua University. Dr Ke was awarded a PhD by the University of Cambridge in 2012 and a bachelor's degree by Tsinghua University in 2007. His research interests include business/innovation ecosystems and network economics, manufacturing system evolution, business ecosystems and business models, technology and innovation management, emerging multinational companies' internationalisation, China and Africa.

Dr Yong Lin is a principle lecturer in Operations Management at the Business Faculty of the University of Greenwich. Dr Lin has spent many years in teaching and research, including being in charge of several research projects funded by the National Natural Science Foundation of China (NSFC) and the 863 Program (National High-Technology Research and Development Program of China). His research interests lie in the fields of operations management and supply chain management, specifically in manufacturing strategy, supply chain collaboration, logistics service design, inventory modelling and control, business ecosystems, and innovation. 
Dr Jiang $\mathrm{Yu}$ is a professor at the Institute of Policy and Management, Chinese Academy of Sciences (CASIPM). His main research interests include technology management and policy, emerging technology management and strategy environments.

Miss Yue Zhang is a PhD candidate at the Institute of Policy and Management, CASIPM. Her research interests are business ecosystems and emerging industries. 


\section{Manufacturing Strategies for the Ecosystem-Based Manufacturing System in the Context of 3D Printing}

This paper aims to investigate the manufacturing strategies for the manufacturing systems in the context of 3D printing, referring to ecosystem-based manufacturing systems, rather than firm-based and network-based ones. A case study approach was adopted for this research, as the data was mainly collected via semi-structured interviews with staff members of companies in China. Besides the elements of strategic choices and manufacturing capabilities identified in the extant literature, this research verified three additional strategic choice elements (functional role, platform and solution) and identified two factors (platform openness and solution diversity) to classify an ecosystem-based manufacturing system. Meanwhile, four manufacturing capabilities of the ecosystem-based manufacturing system have been identified: collaborative manufacturing flexibility, rapid thriftiness ability, self-customisation and co-evolved design capability. This research results contribute to the area of manufacturing strategy via expanding its view from the firm and network levels to the ecosystem level. Meanwhile, the research results present operations managers with an understanding of the strategic choices and manufacturing capabilities of an ecosystem-based manufacturing system in the context of $3 \mathrm{D}$ printing.

Keywords: manufacturing strategy; manufacturing systems; strategic choices; manufacturing capability; business ecosystem; 3D printing 


\section{Introduction}

Nowadays, emerging technologies such as 3D printing are attracting huge attention from both academia and practitioners. With all its benefits, such as reducing tooling and assembly costs, reducing time to market and advancing innovation, 3D printing technology is now regarded as one of the disruptive technologies that will dramatically change traditional manufacturing industries (Achillas, Tzetzis and Raimondo 2017; Long et al. 2017). However, one key challenge facing manufacturing industries is how manufacturers can gain the benefits of such emerging technologies (Niaki and Nonino 2017) via appropriate manufacturing strategies.

While when discussing manufacturing strategies, prior studies have mainly focused on strategic choices and manufacturing capabilities (Chatha and Butt 2015). The strategic choices in decision areas, such as production planning and control, organisational structure and control, sourcing, process technology, and facilities and human resources (Miltenburg 2005), determine the configuration of a manufacturing system, which in turn affects its manufacturing capabilities (Choudhari, Adil and Ananthakumar 2012). Early research was mainly about firm/plant-level choices on the structural and infrastructural elements and their connections in a manufacturing system, as well as the manufacturer's key task priorities and manufacturing capabilities (Voss 2005). However, in the past three decades, globalisation has urged firms to distribute their manufacturing sites globally, leading to the formation of a more complex global manufacturing network (Feldmann et al. 2013). Hence, studies on manufacturing strategies have extended their focus to the network level, focusing on the integrated decisions of networks of factories (Olhager and Feldmann 2017).

Moreover, in recent years, with the introduction of emerging technologies like 3D printing, the manufacturing system and its activities actually involve more stakeholders: not only suppliers, manufacturers, distributors and customers but also complementors who provide complementary products/services (Gawer and Cusumano 2014), competitors, universities, 
research institutions, industry associations, regulators and government agencies. Such a business community comprising individually autonomous but interconnected stakeholders is defined as a business ecosystem (Iansiti and Levien 2004a; Moore 2006). It is believed that business competition has evolved from the firm level towards the extra-organisational business ecosystem level (Rong et al. 2015). Meanwhile, in order to enhance value creation, it is necessary to broaden the organisational focus from the individual firm to a business ecosystem perspective (Baldwin 2012). Hence, in this research, we define the manufacturing system as an ecosystem-based system, rather than a firm-based or network-based one, in order to reflect its complex structure and relationships.

However, within current literature on manufacturing strategies and 3D printing, it is mainly focused on only firm level considering impacts and benefits of 3D printing on manufacturing systems (Baumers et al., 2017; Gardanm 2016; Long et al. 2017; Niaki and Nonino 2017), there is no research tackling manufacturing strategies at the ecosystem level under the context of 3D printing. Moreover, there are very little empirical studies (Li et al., 2017; Wang et al. 2016). In light of these research gaps, this paper aims to identify the manufacturing strategies in terms of strategic choices and manufacturing capabilities for the ecosystem-based manufacturing system, and to bring practical guidance to practitioners in the manufacturing industries when adopting 3D printing. Hence, the research question defined in this research was as below:

$R Q$ : What manufacturing strategies (strategic choices and manufacturing capabilities) support the ecosystem-based manufacturing system in gaining competitive advantage in the context of $3 D$ printing?

In order to answer this research question, we conducted case studies in the Chinese 3D printing industry. One of the key reasons why this research focused on the Chinese market is because its 3D printing technology is growing rapidly and has significantly influenced 
traditional manufacturing industries (Long et al. 2017; Wang et al. 2016). Meanwhile, 3D printing technology has been selected as one of the cutting-edge technologies that will reshape China's competitiveness and will help to rebuild the Chinese manufacturing industries. It was believed that the results of this research would elicit valuable and comprehensive observations and implications from the market. Meanwhile, it may also prove to be a useful contribution to other countries' understanding of managing manufacturing systems for emerging technologies.

The research results contribute to the area of operations management by bringing understandings and insights on manufacturing system and its strategies at ecosystem level under the context of 3D printing. Firstly, the foundation of this research is based on current research on firm/network level, but this research expands it to the ecosystem-based level. Secondly, this research verifies the elements of the strategic choices and manufacturing capabilities of an ecosystem-based manufacturing system in the context of 3D printing. Finally, it provides industrial practitioners with practical guidance on what type of manufacturing system they possibly can position themselves in, and what appropriate capabilities should be built for an ecosystem-based manufacturing system in particular under the context of emerging technologies like 3D printing.

\section{Literature Review}

It is not easy to decide appropriate manufacturing strategies for a manufacturing system to achieve competitive advantage. Ward et al. (1996) noted that manufacturing strategy embodies the choices among the most needed set of manufacturing capabilities for a business unit and the investments required to build that set of capabilities. In current literature, strategic choices and manufacturing capabilities are the two main content themes of manufacturing strategy (Chatha and Butt 2015). Hence, in this research, we focus on these two elements to study manufacturing strategies for the ecosystem-based manufacturing system. 


\subsection{Manufacturing Systems}

Traditional studies on manufacturing systems focusing on firms or factories have primarily centred on strategic or operational decisions regarding plants, equipment, production planning and control, labour and staffing, product design and engineering, and organisation and management at the firm/factory level (Avella, Vazquez-Bustelo and Fernandez 2010; Hayes and Wheelwright 1984). These optimisation decisions normally seek to achieve objectives like higher productivity, cost efficiency, flexibility and improved quality of factory operations (Choudhari, Adil and Ananthakumar 2012).

With the fast pace of globalisation in the last three decades, the vast majority of manufacturing is carried out in dispersed locations (Olhager and Feldmann 2017). As a result, studies on manufacturing systems have been extended to the network level. For example, studies have investigated the international manufacturing network (Feldmann et al. 2013; Miltenburg 2009; Shi 2003; Shi, Gregory and Naylor 1997), which is a factory network consisting of geographically dispersed but interdependently coordinated factories/plants. These studies have focused on the integration and coordination issues of dispersed factory networks, especially the choice of location, the number of factories and the role of each factory (Jaehne et al. 2009; Paquet, Martel and Montreuil 2008).

Nowadays, with the rapid development of various emerging technologies, like 3D printing, manufacturing activities involve a wider range of stakeholders. Hence, success is increasingly dependent on cooperation and co-evolution with other stakeholders in the business ecosystem (Iansiti and Levien 2004a, 2004b; Moore 1996, 1998; Zhang et al. 2017). As a result, competition is no longer limited to being between individual firms, as firms now rely on a network of business partners; thus, the competition is business ecosystem against business ecosystem (Gawer and Cusumano 2014; Rong et al. 2015). Meanwhile, it is believed that 3D 
printing technology could impact on future value creation among the stakeholders within business ecosystems (Hämäläinen and Ojala 2015). Furthermore, from the perspective of organisational design theory, individual corporations are no longer adequate in serving as the primary unit of analysis (Baldwin 2012). It is suggested that organisation designers should think about how to distribute property rights, people and activities across numerous selfgoverning enterprises in ways that are advantageous for various stakeholders in the business ecosystem, as well as for the designer's own firm or community (Baldwin 2012).

Hence, this research adopted a business ecosystem perspective to investigate manufacturing strategies for the manufacturing system in the context of emerging technologies. This is defined as an ecosystem-based manufacturing system focusing on collaborative relations between a range of stakeholders, which is different form the firm-based manufacturing system focusing on the plant's managerial optimisation (Skinner 1974) and the network-based manufacturing system focusing on process integration and coordination among dispersed plants or suppliers (Oliff et al. 1989).

\subsection{Manufacturing Strategies - Strategic Choices}

For the firm-based manufacturing system, the strategic choices, namely stakeholder roles and their connections, are regarded as the key operating mechanism among the companies in the manufacturing system and include two key elements: structure and infrastructure (Garrido, Martín-Peña and García-Muiña 2007) (see Table 1). The structural elements refer to the static levers controlling the architectural configuration of a manufacturing system, determining the configurational structure of the firm-based manufacturing system, while the infrastructural elements refer to the dynamic levers controlling the operational mechanism of the manufacturing system, which are more focused on daily operations and accumulative improvement (Hayes and Wheelwright 1984). 
Table 1. Elements of strategic choices for different manufacturing systems

\begin{tabular}{|c|c|c|c|}
\hline & \multicolumn{3}{|l|}{ Manufacturing system } \\
\hline & $\begin{array}{l}\text { Firm-based system } \\
\text { (Hayes and Wheelwright } \\
\text { 1984) }\end{array}$ & $\begin{array}{l}\text { Network-based system (Shi and } \\
\text { Gregory 1998) }\end{array}$ & Ecosystem-based system \\
\hline $\begin{array}{l}\text { Structural } \\
\text { elements }\end{array}$ & $\begin{array}{l}\text { - Plant capacity } \\
\text { - Facilities } \\
\text { - Technology } \\
\text { - Vertical integration }\end{array}$ & $\begin{array}{l}\text { - Factory characteristics (as per } \\
\text { whole left column) } \\
\text { - Geographic dispersion } \\
\text { - Horizontal coordination } \\
\text { - Vertical coordination }\end{array}$ & $\begin{array}{ll}\bullet & ? \\
\bullet & ? \\
\bullet & ? \\
- & \text { As per left two columns }\end{array}$ \\
\hline $\begin{array}{l}\text { Infrastructural } \\
\text { elements }\end{array}$ & $\begin{array}{l}\text { - Workforce } \\
\text { - Quality } \\
\text { - Production planning / } \\
\text { material control } \\
\text { - Organisational } \\
\text { structure } \\
\end{array}$ & $\begin{array}{l}\text { - } \text { Dynamic response mechanism } \\
\text { - Product lifecycle and knowledge } \\
\text { transfer within international } \\
\text { manufacturing network } \\
\text { - Operational mechanism }\end{array}$ & $\begin{array}{ll}\bullet & ? \\
\bullet & ? \\
\bullet & ? \\
- & \text { As per left two columns }\end{array}$ \\
\hline Focus & - Internal resources & $\begin{array}{ll}\text { - } & \text { Internal resources } \\
\text { - } & \text { External resources } \\
\end{array}$ & $\begin{array}{ll}\text { - External resources } \\
\text { - Internal resources } \\
\end{array}$ \\
\hline
\end{tabular}

For a network-based manufacturing system, the strategic choices indicate the locations of plants and the inter-facility allocation of resources along the value chain (Feldmann et al. 2013), and the system is more focused on knowledge transfer and network evolution (Shi and Gregory 1998) (see Table 1). The networked plants and their coordination, including both horizontal and vertical integration, are the fundamental determinants of competitiveness (Rudberg and Martin West 2008). Strategic decisions on structural and infrastructural elements will greatly influence manufacturing capabilities and manufacturing performance (Corbett 2008).

The development of structural and infrastructural elements complies with the resourcebased view (RBV) (Barney, Wright and Ketchen 2001) of how to obtain competitive advantage at both the factory and network levels (Colotla, Shi and Gregory 2003) via internal firm-level resources. However, within the fast-changing business environment nowadays, firms cannot have all necessary resources but have to rely also external partners to access necessary resources to gain and sustain competitive advantage (Lavie 2006). This extended resourcebased view (ERBV) (Eisenhardt et al. 1996; Arya and Lin 2007) emphasizes that partner 
resources within the collaborative network will contribute to organizational competitive advantage. Here considering the ecosystem-based manufacturing system, with more stakeholder involved in the manufacturing system as explained before, it is important that the strategic choices should be considered with an extended view from internal to external to look at collaborative relations and external network resources. Compared with traditional RBV, such an ERBV can explain the gaining of competitive advantages in a more integrated way (Lavie 2006) emphasizing the external resources and the impacts of interconnected firms within the ecosystem.

Hence, using the identified elements for firm- and network-based manufacturing systems as in Table 1, this research expands the research to ecosystem level aiming to explore the elements of strategic choices for ecosystem level manufacturing system.

\subsection{Manufacturing Strategies - Manufacturing Capabilities}

\section{1) The RBV}

In the current wide range of literature, the discussion of firm-level manufacturing capabilities focuses on those that can provide competitive advantage in terms of cost, quality, delivery and flexibility (Corbett and Claridge 2002) (see Table 2). Such capability research is mainly based on the RBV, arguing that competitive advantage is derived from resources and capabilities (Barney, Wright and Ketchen 2001) and that capabilities can be defined as the abilities with which firms exploit their existing resources, explore potential resources and create value for themselves (Teece and Pisano 1994).

In the last two decades, manufacturing capability research has expanded from the firm level to the network level (Voss 2005). For example, capabilities like communication, innovation and learning, integration, and restructuring have been highlighted in international manufacturing networks (Shi and Gregory 1998) (see Table 2). Due to the complex nature of 
such networks, the discussion of capabilities is more focused on the coordination and integration of the dispersed firms/plants in the manufacturing networks. For an international manufacturing network (Feldmann et al. 2013), manufacturing capabilities can be categorised into resource accessibility, thriftiness ability, manufacturing mobility and learning ability.

While to the ecosystem level, with co-evolution as one of the essential features of the concept of business ecosystem (Moore, 1993), this paper believes it is important to adopt a dynamic capabilities approach to investigate the manufacturing capabilities for the business ecosystem-based manufacturing system. This is based on the fundamentals of the perspective of dynamics capabilities that both resources and capabilities may evolve and change over time (Ambrosini, Bowman and Collier 2009; Helfat and Peteraf 2003).

Table 2. Manufacturing capabilities of three types of manufacturing systems

\begin{tabular}{|c|c|c|c|}
\hline & \multicolumn{3}{|c|}{ Manufacturing system } \\
\hline & Firm-based system & Network-based system & $\begin{array}{c}\text { Business ecosystem-based } \\
\text { system }\end{array}$ \\
\hline Capability & $\begin{array}{l}\text { - } \text { Cost } \\
\text { - Quality } \\
\text { - Delivery } \\
\text { - Flexibility }\end{array}$ & $\begin{array}{l}\text { - Strategic target (resource) } \\
\text { accessibility } \\
\text { - Thriftiness ability } \\
\text { - Manufacturing mobility } \\
\text { - Learning ability }\end{array}$ & $\begin{array}{l}\text { - ? } \\
\text { - ? } \\
\text { - ? } \\
\text { - As per left two columns }\end{array}$ \\
\hline \multirow[t]{2}{*}{ Focus } & $\begin{array}{l}\text { - Efficiency } \\
\text { - Productivity }\end{array}$ & $\begin{array}{l}\text { - Coordination } \\
\text { - Integration }\end{array}$ & $\begin{array}{l}\text { - Collaboration and competition } \\
\text { - Co-evolution }\end{array}$ \\
\hline & - $\mathrm{RBV}$ & $\begin{array}{l}\text { - } \mathrm{RBV} \\
\text { - Dynamic capabilities }\end{array}$ & $\begin{array}{l}\text { - Dynamic capabilities } \\
\text { - }(\mathrm{E}) \mathrm{RBV}\end{array}$ \\
\hline
\end{tabular}

\section{2) Dynamic Capabilities}

The capabilities for both firm- and network-based manufacturing systems are mainly considered under the RBV. However, the RBV has been challenged as a relatively static view on resources, capabilities and competitive advantage (Ambrosini, Bowman and Collier 2009; Barney, Wright and Ketchen 2001; Priem and Butler 2001), and it is argued that the RBV should have a more dynamic perspective in order to understand how firms evolve over time (Danneels 2002; Zahra, Sapienza and Davidsson 2006). 
Especially in the context of emerging technologies, firms face many uncertainties. For one thing, firms need to react quickly to both technological and market uncertainties (McAdam, Bitici and Galbraith 2017). As suggested by the dynamic capabilities approach, firms need to take a more comprehensive view of the environment in which they must compete (Teece 2011); such a view is appropriate to support the analysis of the ecosystem-based manufacturing system when facing industry uncertainties of emerging technologies (Rong, Shi and Yu 2013).

For another, firms need to continuously sense and seize opportunity to proactively address new uncertainties (Teece 2018) arising in the context of emerging technologies. A dynamic capabilities lens will help to capture the fast-changing nature of the emerging industrial system, and to demonstrate how an industrial system evolves by coordinating the ecosystem stakeholders to satisfy market requirements (Shang, Chang and Shi 2012). Furthermore, manufacturing capabilities are actually expected to evolve and change over time in various ways (Sarmiento, Sarkis and Byrne 2010).

In all, these motivated us to investigate the manufacturing capabilities of the ecosystembased manufacturing system with a view of dynamic capabilities, this is based on the current research on firm/network level as indicated in Table 2.

\subsection{Research Framework}

To better understand the ecosystem-based manufacturing systems, it is essential to study manufacturing strategies in terms of strategic choices and manufacturing capabilities at ecosystem level rather than firm/network level, in order to reflect the evolution of manufacturing system under the context of emerging technologies like $3 \mathrm{D}$ printing. The research framework developed is shown in Figure 1. The question marks indicate the elements that this research aimed to explore. 


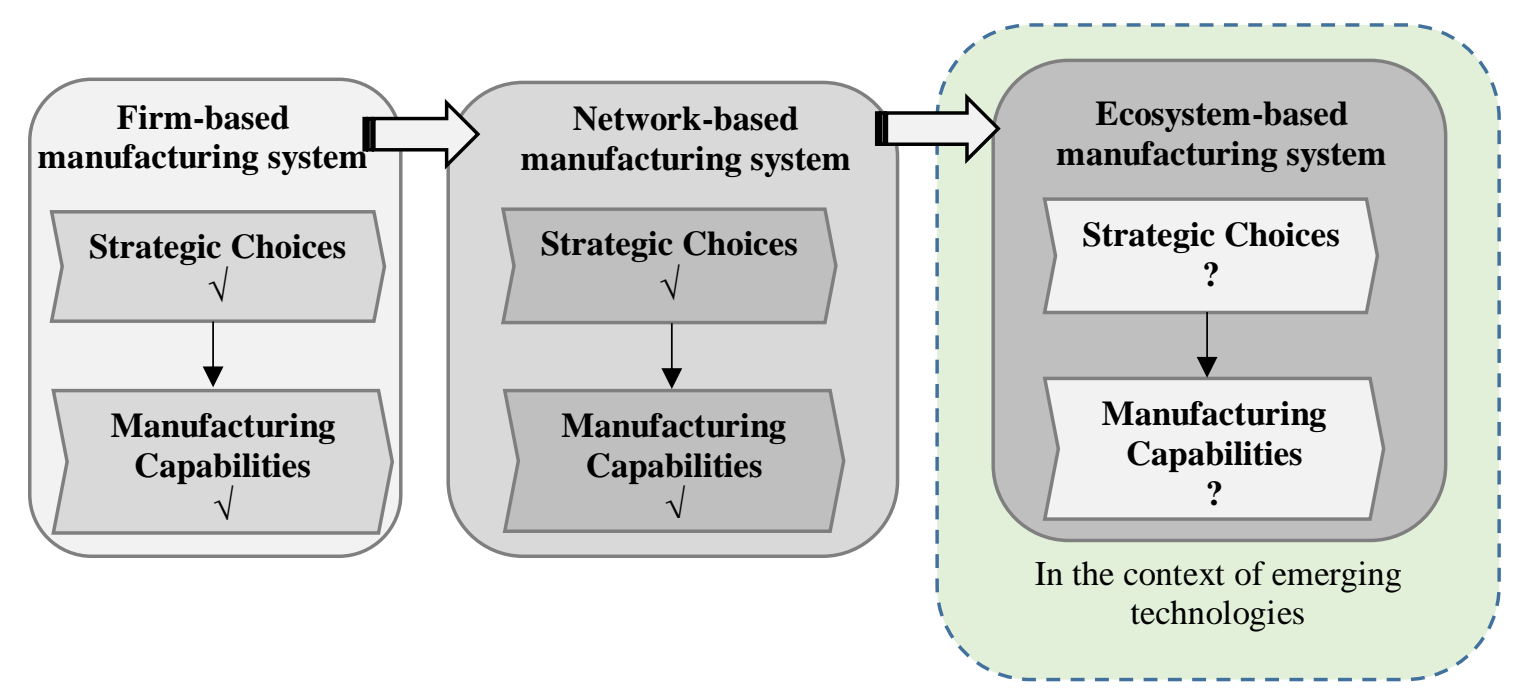

Figure 1. Research framework

\section{Research Methodology}

\subsection{Case Study}

Reflecting the contemporary and complex nature of research in the field of manufacturing strategies with emerging technologies, this study adopted a case study methodology to address the research question (Yin 2014). In order to enable a broad exploration of the research question, multiple case studies were used in this research, with the aim of achieving robust, generalisable and testable theories through the provision of more-compelling evidence (Eisenhardt and Graebner 2007). In order to reflect the comprehensive picture of the implementations of 3D printing technologies in the Chinese market, this study used three categories of case studies (see Table 3), with consideration given to data accessibility and privacy issues. The first category was a single case study with one organisation, which was a university research lab. This was a special case reflecting the context of close relationships among a high-end airplane manufacturer, a university lab and a central government. This single case focused on the university research lab, which had sufficient knowledge of the industry based on its strong relationship with the manufacturer. The second category was a multiple case study with four sub-cases. This category aimed to reflect the fast market growth but with 
a similar pattern. The third category was a single case study with several companies, aiming to reflect the complex structure of ecosystem-based manufacturing systems.

For an ecosystem-based manufacturing system, it is difficult to include all stakeholders in case studies due to the complex nature of a business ecosystem. Hence, this study selected focal firms/organisations using predefined selection criteria, including: having consistently and successfully operated in the field for several years; able to represent the direction, driving force and structural characteristics of the system; and has the potential to become the benchmark company for best practices in the future. These factors were identified through reading industry reports, analysing company reports and consulting industrial and academic experts. An overview of the selected case firms/organisations in this research and their relevant interview details are presented in Table 3. 
Table 3. Overview of the case companies and the interviews

\begin{tabular}{|c|c|c|c|c|c|c|c|c|}
\hline $\begin{array}{l}\text { Case } \\
\text { category }\end{array}$ & $\begin{array}{l}\text { Case } \\
\text { no. }\end{array}$ & Company/organisation & Company/organisation profile & Place & $\begin{array}{c}\text { Role of } \\
\text { interviewee(s) }\end{array}$ & $\begin{array}{c}\text { Number of } \\
\text { interviewees }\end{array}$ & $\begin{array}{c}\text { Average } \\
\text { time } \\
\text { (hrs/person) }\end{array}$ & $\begin{array}{l}\text { Total } \\
\text { (hrs) }\end{array}$ \\
\hline 1 & $\mathrm{C} 1$ & $\begin{array}{l}\text { 3D printing research lab: Beijing } \\
\text { University of Aeronautics and } \\
\text { Astronautics (BUAA Lab) } \\
\text { As focal organisation of Case Cl. }\end{array}$ & $\begin{array}{l}\text { This lab is one of the key partners of the Commercial } \\
\text { Aircraft Corporation of China (COMAC) Ltd, } \\
\text { researching, developing and producing 3D printers and } \\
\text { components for COMAC. }\end{array}$ & Beijing & $\begin{array}{l}\text { Chief scientist / } \\
\text { project leader }\end{array}$ & 3 & 3 & 9 \\
\hline \multirow{7}{*}{2} & $\mathrm{C} 2-1$ & $\begin{array}{l}\text { Longyuan Co., Ltd } \\
\text { As focal firm of Case C2-1. }\end{array}$ & $\begin{array}{l}\text { This firm provides laser sintering 3D printers and } \\
\text { prototyping services to customers mainly from the } \\
\text { aerospace and automobile industries. }\end{array}$ & Beijing & $\begin{array}{l}\mathrm{CEO} / \text { project } \\
\text { manager / sales } \\
\text { manager } \\
\end{array}$ & 3 & 3 & 9 \\
\hline & \multirow[b]{3}{*}{$\mathrm{C} 2-2$} & \multirow{3}{*}{$\begin{array}{l}\text { Hengtong Intelligent Machine } \\
\text { Co., Ltd. } \\
\text { As focal firm of Case C2-2. }\end{array}$} & \multirow{3}{*}{$\begin{array}{l}\text { The lab established this company, which provides laser } \\
\text { sintering 3D printers and prototyping services. } \\
\text { The company was founded by the National Engineering } \\
\text { Research Center of Rapid Manufacturing, Xi'An } \\
\text { Jiaotong University, Xi'An, China. }\end{array}$} & \multirow[t]{3}{*}{ Xi'an } & \multirow{3}{*}{$\begin{array}{l}\text { Global platform } \\
\text { manager / project } \\
\text { manager }\end{array}$} & \multicolumn{3}{|c|}{ Pilot case study } \\
\hline & & & & & & 1 & 1.5 & 1.5 \\
\hline & & & & & & 2 & 1 & 2 \\
\hline & \multirow[t]{4}{*}{$\mathrm{C} 2-3$} & $\begin{array}{l}\text { Wuhan Binhu Mechanical \& } \\
\text { Electrical Co., Ltd } \\
\text { As focal firm of Case C2-4. }\end{array}$ & $\begin{array}{l}\text { This firm mainly provides laser sintering 3D printers and } \\
\text { prototyping services. } \\
\text { The company was founded by the Center of Rapid } \\
\text { Manufacturing, Huazhong University of Science \& } \\
\text { Technology, Wuhan, China. }\end{array}$ & Wuhan & $\begin{array}{l}\text { Sales manager / } \\
\text { project leader }\end{array}$ & 2 & 1 & 2 \\
\hline & & \multirow{3}{*}{$\begin{array}{l}\text { Stratasys } \\
\text { As software supplier of Case C2-1 } \\
\text { and Case C3. }\end{array}$} & \multirow{3}{*}{$\begin{array}{l}\text { Stratasys is an internationally leading company } \\
\text { providing both industrial 3D printers and desktop 3D } \\
\text { printers. }\end{array}$} & \multirow[t]{3}{*}{ Shanghai } & \multirow{3}{*}{$\begin{array}{l}\text { Community referral } \\
\text { manager }\end{array}$} & \multicolumn{3}{|c|}{ Pilot case study } \\
\hline & & & & & & 1 & 1 & 1 \\
\hline \multirow{10}{*}{3} & & & & & & 1 & 1 & 1 \\
\hline & \multirow{9}{*}{$\mathrm{C} 3$} & $\begin{array}{l}\text { TierTime Co., Ltd } \\
\text { As focal firm of Case C3. }\end{array}$ & $\begin{array}{l}\text { This is Asia's leading 3D printer manufacturer; } \\
\text { originally provided industrial 3D printers and then } \\
\text { entered the market for desktop 3D printers in } 2010 .\end{array}$ & Beijing & $\begin{array}{l}\mathrm{CEO} / \text { research } \\
\text { manager / sales } \\
\text { director }\end{array}$ & 4 & 3 & 12 \\
\hline & & \multirow{3}{*}{$\begin{array}{l}\text { Winbo Industrial Co., Ltd } \\
\text { As material supplier to Case } 3 .\end{array}$} & \multirow[t]{3}{*}{ Winbo is a material vendor for desktop 3D printers. } & \multirow[t]{3}{*}{ Shanghai } & \multirow[t]{3}{*}{ Project manager } & \multicolumn{3}{|c|}{ Pilot case study } \\
\hline & & & & & & 1 & 1 & 1 \\
\hline & & & & & & 1 & 1 & 1 \\
\hline & & $\begin{array}{l}\text { Suntop-tech } \\
\text { As material supplier of Case } 3 .\end{array}$ & $\begin{array}{l}\text { This is a leading provider of 3D-printing-centric design- } \\
\text { to-manufacturing solutions, including 3D printers and } \\
\text { print materials for both industrial and consumer markets. }\end{array}$ & Beijing & Sales manager & 1 & 1 & 1 \\
\hline & & \multirow{3}{*}{$\begin{array}{l}\text { ZWCAD Software Co., Ltd } \\
\text { As software supplier of Case } 3 .\end{array}$} & \multirow{3}{*}{$\begin{array}{l}\text { This firm provides professional software for industrial } \\
\text { applications. }\end{array}$} & \multirow[t]{3}{*}{ Shanghai } & \multirow{3}{*}{$\begin{array}{l}\text { Key account } \\
\text { manager / sales } \\
\text { director }\end{array}$} & \multicolumn{3}{|c|}{ Pilot case study } \\
\hline & & & & & & 1 & 1.5 & 1.5 \\
\hline & & & & & & 2 & 1 & 2 \\
\hline & & $\begin{array}{l}\text { Autodesk } \\
\text { As software supplier of Case } 3 .\end{array}$ & $\begin{array}{l}\text { This internationally leading company provides } \\
\text { engineering design software for applications like 3D } \\
\text { printing. }\end{array}$ & Beijing & $\begin{array}{l}\text { Research manager / } \\
\text { policy manager }\end{array}$ & 2 & 1 & 2 \\
\hline \multicolumn{8}{|c|}{ In total (including pilot case studies): } & 46 \\
\hline
\end{tabular}




\subsection{Data Collection}

Following the methods of Siggelkow (2002), data collection was carried out in four stages, with the interview question guide (see Table 4) aiming to capture both historic and developmental data to reflect the evolution of manufacturing systems with the emerging technologies.

Table 4. List of interview questions

\begin{tabular}{l}
\hline 1) Background Information \\
- Please introduce your company/organisation and its products/services. \\
- What are the driving forces behind your organisation developing/implementing 3D printing \\
technologies? \\
- Please describe your position in the market. \\
\hline 2) Strategic Choices \\
- Please give a list of your major partners and explain the relationships and how you work together. \\
- Please explain how you manage the partnerships; if possible, please give examples. \\
- Please describe your business process and explain the key decision areas. \\
3) Manufacturing Capabilities \\
- What are the key success factors of your business? \\
- What are the key manufacturing capabilities that make your organisation different from others? Or \\
what manufacturing capabilities have been developed in the last five years? \\
- What manufacturing capabilities should be built to gain competitive advantage?
\end{tabular}

In stage one (April-September 2013), we reviewed company documents and collected news and reports on $3 \mathrm{D}$ printing to learn about the general development of the industry. We started to sort the archival data on companies' strategic directions and driving forces. In the second stage (October 2013 - March 2014), we conducted pilot case studies with four companies/organisations and then used a snowball sampling strategy to identify and select other representative case firms via these four companies' industry contacts. The third stage (April 2014 - December 2015) involved in-depth interviews. The interviewees' positions ranged from CEO, product manager, project manager and sales manager to chief scientist. The interviews were conducted following a predesigned framework (see Table 4), which was pretested to ensure data reliability and construct validity (Gibbert, Ruigrok and Wicki 2008). In 
the fourth stage (January-June 2016), further opinions of these informants were elicited by email and telephone to validate the data collected. Considering the complexity of this study, the archival, online document and interview data was cross-validated before use in order to ensure the triangulation of the data collected (Yin 2014).

\subsection{Data Analysis}

After data collection, the data was coded (Auerbach and Silverstein 2003) for further analysis by following the framework shown in Figure 2. Two techniques for the two key stages of data coding were used. First, we started open coding by identifying first-order codes, which were terms to identify the different types of configuration and capability focuses. Secondly, we conducted axial coding (Strauss and Corbin 1997) to identify relationships between these firstorder codes, in order to integrate them into the higher-order codes.

Through refining and comparing the transcripts, we coded the elements of strategic choices as functional role, platform and solution, and we coded the elements of manufacturing capabilities as collaborative manufacturing flexibility, rapid thriftiness ability, selfcustomisation and co-evolved design capability.

After these two coding stages, we tried to combine the key second-order codes into theoretical constructs and to build an integrated framework of the strategic choices and manufacturing capabilities of the ecosystem-based manufacturing system in the context of 3D printing technology.

\subsection{Summary of the Case Study Data}

The data was inductively analysed, classified and coded according to the phrases, terms and labels used by the interviewees. A summary of the case studies is presented in Table 5. 


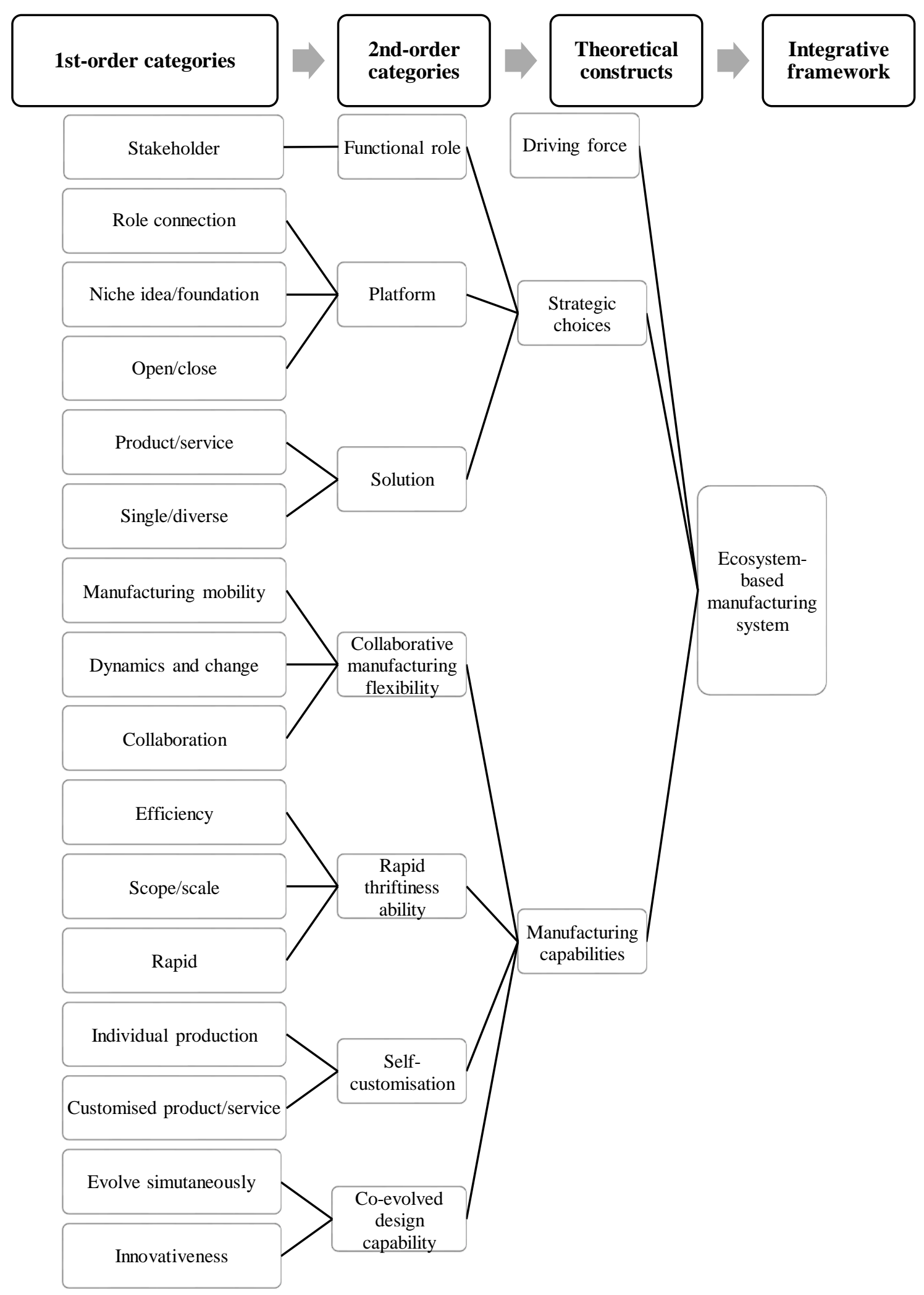


Figure 2. Data analysis process 
Table 5. Summary of the case studies

\begin{tabular}{|c|c|c|c|c|}
\hline & & Case category 1 & Case category 2 & Case category 3 \\
\hline Driver & & Government's R\&D investment and demand & Quick prototyping for industrial product design & $\begin{array}{l}\text { Personal interests or initial ideas for } \\
\text { designers, schools and individual consumers }\end{array}$ \\
\hline \multirow[t]{3}{*}{$\begin{array}{l}\text { Strategic } \\
\text { choices }\end{array}$} & Functional role & $\begin{array}{l}\text { - System integrator: BUAA } \\
\text { - Material vendor: BUAA } \\
\text { - Key component suppliers: BUAA, Rofin and } \\
\quad \text { Trumpf } \\
\text { - Software supplier: Qingdao R\&D } \\
\text { - 3D dataset supplier: BUAA }\end{array}$ & $\begin{array}{l}\text { (taking Case C2-1 as an example) } \\
\text { - System integrator: Longyuan } \\
\text { - Material vendor: Longyuan } \\
\text { - Key component suppliers: Scanlab and Coherent } \\
\text { - Software suppliers: Materialase and Siemens } \\
\text { - 3D dataset supplier: Longyuan }\end{array}$ & $\begin{array}{l}\text { - System integrator: TierTime } \\
\text { - Material vendors: TierTime and Winbo } \\
\text { - Key component suppliers: TierTime, } \\
\text { Xitong and open-source hardware } \\
\text { - Software suppliers: TierTime and open- } \\
\text { source software } \\
\text { - 3D dataset suppliers: Autodesk and } \\
\text { ZWCAD }\end{array}$ \\
\hline & Platform & $\begin{array}{l}\text { - The BUAA designs the architecture and } \\
\text { produces the key components, like the } \\
\text { nozzle and main board, while the laser is } \\
\text { bought from Rofin and Trumpf } \\
\text { - The BUAA produces the metal powder } \\
\text { material in house and relies on Qingdao } \\
\text { R\&D for software for the 3D printing } \\
\text { process } \\
\text { The BUAA outsources the manufacturing of } \\
\text { the 3D printer to a third-party manufacturer }\end{array}$ & $\begin{array}{l}\text { - Longyuan designs the architecture and then } \\
\text { assembles the 3D printers with external } \\
\text { components and software bought from companies } \\
\text { like IPG, Microsoft and Materialase } \\
\text { - Longyuan prints functional components and } \\
\text { moulds its own 3D printers and powdered materials }\end{array}$ & $\begin{array}{l}\text { - TierTime develops the printers' } \\
\text { architecture and key components through } \\
\text { indigenous technology accumulation } \\
\text { - TierTime creates the software and } \\
\text { materials by modifying open-source } \\
\text { hardware and software } \\
\text { - There are many companies supplying } \\
\text { open-source materials, components and } \\
\text { software } \\
\text { - The 3D dataset platform was gradually } \\
\text { nurtured by application software suppliers } \\
\text { like Autodesk and ZWCAD }\end{array}$ \\
\hline & Solution & $\begin{array}{l}\text { Provide simplified solutions that focus on } \\
\text { metal components in the aerospace industry }\end{array}$ & $\begin{array}{l}\text { Provide diversified solutions ranging from rapid } \\
\text { modelling to rapid metal casting }\end{array}$ & $\begin{array}{l}\text { Provide diversified solutions according to } \\
\text { individuals' designs }\end{array}$ \\
\hline \multirow[t]{4}{*}{$\begin{array}{l}\text { Manufacturing } \\
\text { capabilities }\end{array}$} & $\begin{array}{l}\text { Collaborative } \\
\text { manufacturing } \\
\text { flexibility }\end{array}$ & $\begin{array}{l}\text { Minimise the required materials and steps to } \\
\text { bring the large hard-to-disassemble parts to } \\
\text { market }\end{array}$ & Focus on cost and time & Focus on reducing production costs \\
\hline & $\begin{array}{l}\text { Rapid thriftiness } \\
\text { ability }\end{array}$ & $\begin{array}{l}\text { Enhance manufacturing efficiency and } \\
\text { minimise production costs }\end{array}$ & $\begin{array}{l}\text { Minimise prototyping time and costs through rapid } \\
\text { modelling and rapid metal casting }\end{array}$ & $\begin{array}{l}\text { Focus on providing personalised } \\
\text { products/services }\end{array}$ \\
\hline & $\begin{array}{l}\text { Self- } \\
\text { customisation }\end{array}$ & Provide specific designs to key customers & Provide a customised prototyping service & $\begin{array}{l}\text { Provide feasible 3D printers and databases } \\
\text { for individuals to print customised items }\end{array}$ \\
\hline & $\begin{array}{l}\text { Co-evolved } \\
\text { design capability }\end{array}$ & Focus on specific technology & $\begin{array}{l}\text { Quickly test the feasibility of product concepts and } \\
\text { provide feedback on the design flaws of prototypes }\end{array}$ & $\begin{array}{l}\text { Provide various low-cost desktop 3D } \\
\text { printers for personal interest or initial idea } \\
\text { prototyping }\end{array}$ \\
\hline
\end{tabular}




\section{Findings and Discussion}

\subsection{Three Elements of Strategic Choices}

The research results highlight three essential elements of strategic choices for an ecosystembased manufacturing system: functional role, platform and solution.

\subsubsection{Functional Role}

Besides collaborative relations and interactions, the results indicate that different actors are engaged in and committed to the development of the manufacturing system via being responsible for single or multiple functions. This implies with the idea of extended RBV that external partner resources play increasing important roles in gaining and sustain competitive advantages (Lavie 2006). Meanwhile, this is supported by neo-institutional theory, which states that roles can be formally constructed to carry specific rights and responsibilities and to have varying access to material resources, or they can emerge informally over time (Scott 2013). The functional roles identified in this research are presented in Figure 3.

The results highlight that an appropriate understanding of these roles can facilitate the efficient organisation of an ecosystem-based manufacturing system and can make different roles work well with each other. For instance, the keystone player is the system integrator, which either owns the technology or imports the technology into its business and enables all members to invest in a shared future through integrating offerings from suppliers and delivering devices/services to end users (Iansiti and Levien 2004c). Other roles also perform their own functions (such as supplying materials and components or providing software and datasets) to ensure the healthy development and operation of the ecosystem-based manufacturing system. 


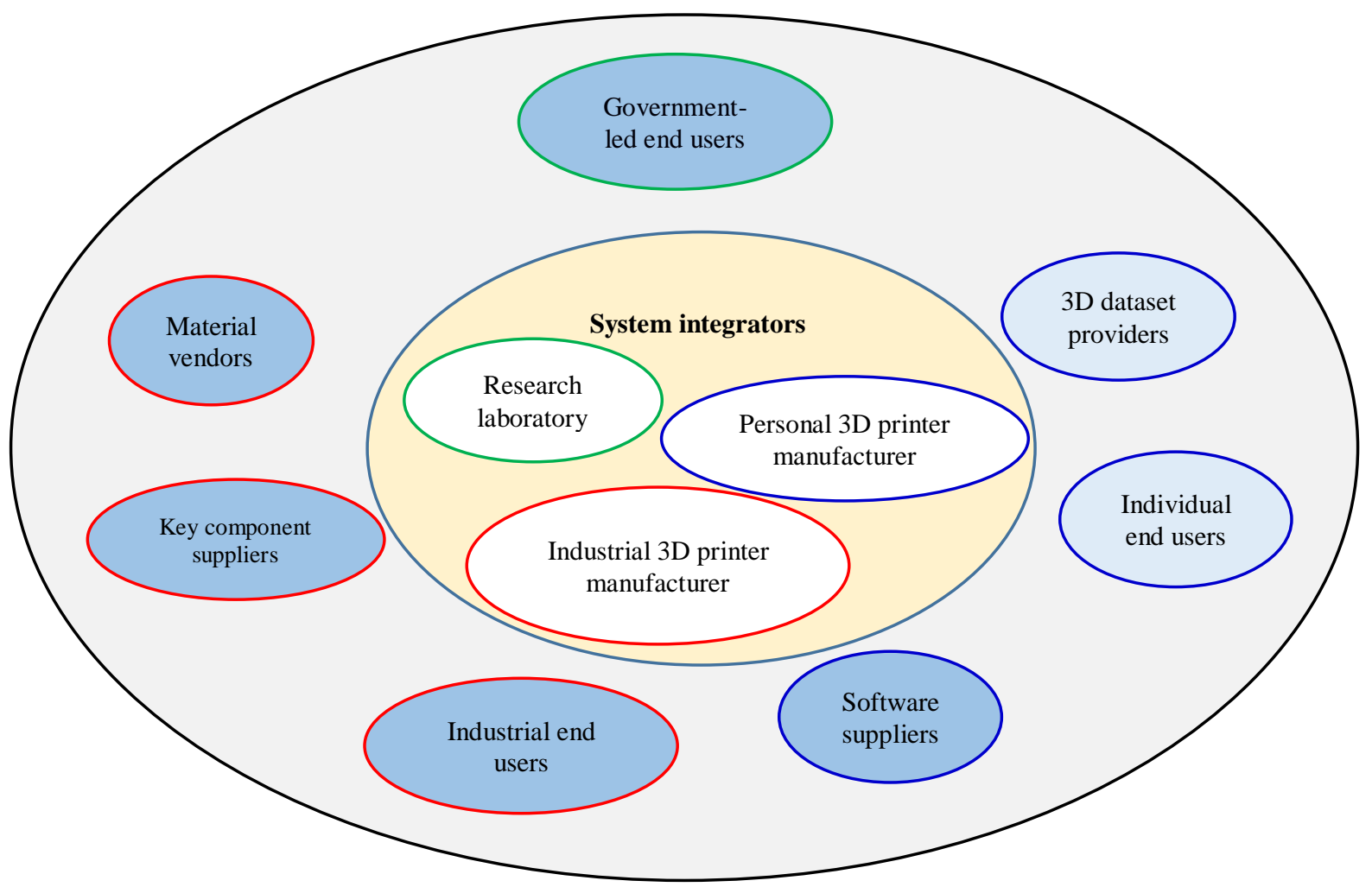

Figure 3. 3D printing ecosystem-based manufacturing system mapping

The research results also indicate that the role being acted out is not fixed but is adaptable to the changing business environment. For example, the keystone or focal firm will be a role played not only by industrial firms but also by organisations like university labs, government agencies and other communities. For example, in Case 1, Case 2-2 and Case 2-3, university research labs play a critical role in the manufacturing system; the focal companies in Cases 2-2 and 2-3 were founded by and relied on university research labs for their strong research capabilities in 3D printing technologies. To some extent, university research labs are leading the development and growth of the industry via developing 3D printing technologies and commercialising the technologies and products.

\subsubsection{Platform}


The results highlight that close collaboration among functional roles is required to co-evolve with each other around a platform, which is a set of technological building blocks and complementary assets that provide a foundation of reusable common components or technologies to outside firms (Gawer and Cusumano 2014). The platform acts as a connection medium that all functional roles can access and collaborate on to easily create various products/services and ideas. In general, the keystone role provides the platform (either a technology or a product/service) and encourages other niche players, specialists or complementors to add value to it (Iansiti and Levien 2004c).

Around the platform, actors' interaction and collaboration are essential to the performance of the whole manufacturing system, which is in line with the idea of extended RBV on the importance of external collaborative network (Arya and Lin 2007). Close communication and high levels of collaboration between the focal firm and complementors will likely generate a healthy ecosystem (Rong et al. 2015) and will enhance the legitimacy of the ecosystem (DiMaggio and Powell 1983) from the view of neo-institutional theory. Hence, the openness of the platform has a significant influence on the performance of the whole manufacturing system.

\subsubsection{Solution}

A solution is a package with rich and full core value, as defined by Moore (1996). The solution could be a simple single product, like the focused metal components in Case 1, or diversified solutions, as with the rapid modelling and rapid metal casting in Case 2-1.

If the focal firm encourages more partners to contribute to its platform and allows ecosystem partners to interact closely with each other, this helps to create diversified solutions efficiently and effectively. It will also create more opportunities for ecosystem partners to get involved in the product development process (Rong and Shi 2014). One of the key initiatives 
of collaboration is to embrace ideas and contributions from all relevant functional roles to create value together, and this principle also generates cross-industry open innovation (Chesbrough 2005).

\subsection{Classification of Ecosystem-Based Manufacturing Systems}

The research results identify two determinant factors to classify ecosystem-based manufacturing systems into groups: platform openness and solution diversity (see Figure 4).

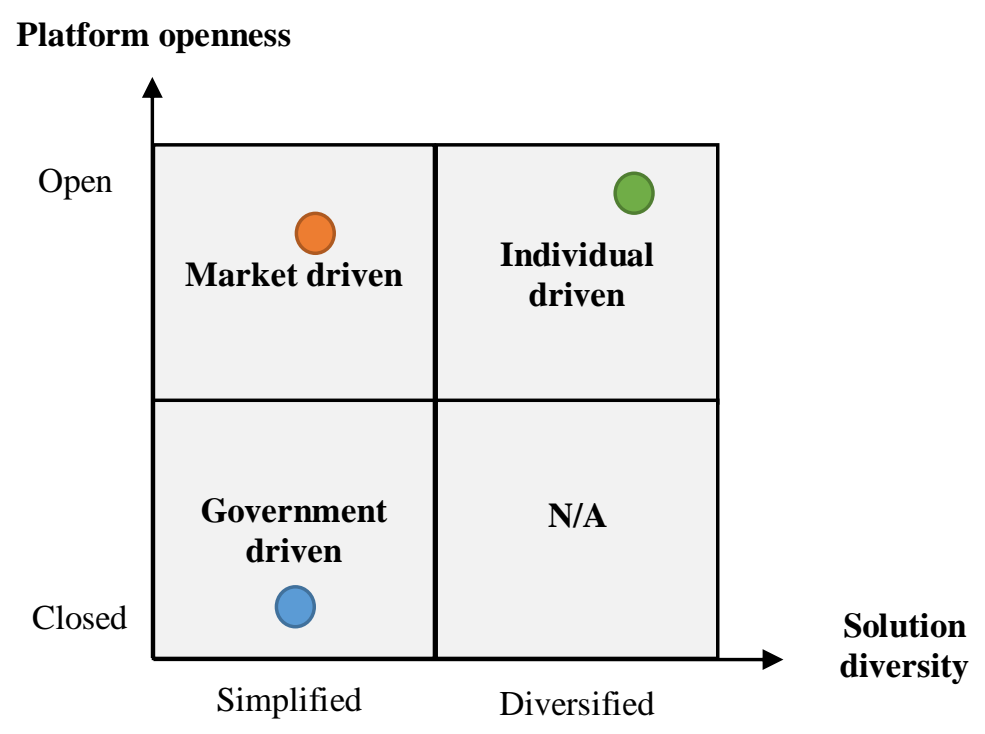

Figure 4. Determinant factors and classification of ecosystem-based manufacturing systems

\subsubsection{Two Determinant Dimensions}

As discussed above, the platform is considered a new element of strategic choice in the manufacturing strategy, and it is different from depending on products and processes to classify a firm-based manufacturing system (Hayes and Wheelwright 1984) or geographic dispersion and manufacturing coordination to classify a network-based manufacturing system (Shi and Gregory 1998). 
First, different levels of platform openness are designed from the beginning and coevolve with the emergence of each configuration. With a closed platform (as in Case 1), the focal firm/organisation plays several roles, like designing the architecture, producing the key components and assembling the products in a closed system that is driven by the government. This system has few linkages with external players. With a less open platform (as in Case 2), the focal firm aims to control the technological development direction of the ecosystem and to scale up product volumes by closing its product design platform and opening only the supplementary part of its core technology. As for the open platform (as in Case 3), the focal firm co-evolves with its partners, and firms seek significant support from each other.

Second, even if the platforms are similar, the outcome of the manufacturing system could be different. Hence, the solution diversity could vary greatly. For example, the government-driven platform produces very complicated but not diversified products. The market-driven platform is similarly closed but produces greatly diversified solutions because the firms provide different modules and design services, which enables solution diversity.

\subsubsection{Three Classifications}

With these two determinants, ecosystem-based manufacturing systems can be positioned differently, as demonstrated in Figure 4. There is an empty quadrant in the bottom right. This is because if the platform is open, it will allow more complementors to be plugged in, leading to more innovation (Chesbrough 2005; Gawer and Cusumano 2014). In this situation, the solution diversity should be relatively high. Hence, there was no configuration for high platform openness but low solution diversity identified in this research.

Classification 1: Government driven. This type of manufacturing system is built up mostly because of demand from largely government-controlled industries like aerospace, which requires many complicated parts. The system integrator produces materials and key components internally, and the production system co-evolves with the requirements of the end 
users (government led), which produce the aircraft. Along with the evolution of the aircraft, the system integrator upgrades materials, key components and system architectures accordingly to meet the demands of end users. However, it is much more closed than the other two classifications.

Classification 2: Market driven. The manufacturing system produces 3D printing devices and provides some industrial-level 3D printing services, such as fulfilling the demand for prototyping in product design. The key components and software of 3D printers in this industrial domain could be accessed from either international or domestic industrial players. The system integrator relies heavily on external material vendors, key component suppliers and software suppliers for system upgrading. System production co-evolves with external resources in the business ecosystem. This system is less open and is dominated by some key industrial partners.

Classification 3: Individual driven. This is an open community system where individuals' interests and creativity serve as the main drivers. Open-source hardware and software dominate this industrial domain. The individuals co-evolve with the open-source hardware and software platforms in a reciprocal cycle in which individuals contribute to the expansion of open-source platforms and the platforms benefit individuals through their enlarged resources. It is very open to embracing all individuals' contributions, and all passionate individuals could contribute their designs and share them online.

An interesting result is that these three classifications co-exist in the Chinese 3D printing market, and each classification complements the others with its own focus. This complies with the intuitional perspective (Shi et al. 2017), which suggests that the ecosystem as an institutional field is a set of organisations characterised by structured networks and relations and a set of shared institutions. 


\subsection{Manufacturing Capabilities of the Ecosystem-Based Manufacturing System}

In addition to the capabilities identified in earlier studies in both firm-based and network-based manufacturing systems, the research results identify four additional capabilities of the ecosystem-based manufacturing system: collaborative manufacturing flexibility, rapid thriftiness ability, self-customisation and co-evolved design capability.

\subsubsection{Collaborative Manufacturing Flexibility}

3D printing technologies make it easier to produce many complicated components, which has brought about a greater degree of manufacturing flexibility (Berman 2012) for the whole business ecosystem. This identified capability highlights the collaborative nature of building manufacturing flexibility with ecosystem partners, which is different from the general flexibility focused on individual firms in firm- or network-based manufacturing systems (Jain et al. 2013; Pérez Pérez, Bedia and Fernández 2016). This means that manufacturing flexibility is built upon close collaborative activities between the focal firm and key customers in Case 1 or between the focal firm, key partners and key customers in Cases 2 and 3. As highlighted by the project leader in the BUAA's case, 'the application of laser 3D printing technology enhanced our flexibility by minimising the required materials and reducing the steps to bring the large, hard-to-disassemble parts to market and reducing the external suppliers'. This capability reflects the ability of integrating internal and external stakeholders to collaborate with each other to build manufacturing flexibility to satisfy customers and capture value (Teece and Leih, 2016).

\subsubsection{Rapid Thriftiness Ability}

Further to the thriftiness ability discussed by Shi and Gregory (1998), one feature emphasised by the research results is that thriftiness is enhanced significantly by rapid processing 
technologies, including rapid modelling, rapid casting and rapid prototyping. Hence, in this research, we coded it as rapid thriftiness ability. For instance, the BUAA team developed and produced a windshield frame in a much shorter time and at only one-tenth of the cost of that of Western companies in 2009. In the market-driven case, Longyuan also enhanced customers' R\&D thriftiness through rapid modelling and rapid metal casting. As one sales manager indicated, with such thriftiness, the firm could 'print functional parts within a few days after the initial designs were completed', which significantly enhanced the firm's efficiency and performance. This capability reflects the sensing feature of dynamic capabilities that enables firms to explore technological opportunities and even latent market demand (Teece 2007, 2011).

\subsubsection{Self-Customisation}

The reason for this coded capability is that products can not only be customised by end users (individuals or industry customers) but can also be produced by them, with the existing database supported by software companies like Autodesk and ZWCAD. This is different from the general mass customisation (Choi and Guo 2017) concept, in which products are customised but still made by manufacturers. Moreover, with self-customisation capability, the ecosystem-based manufacturing system is able to achieve better customised products and services on a large scale (Anderson and Sherman 2007). For example, the individual-driven configuration could provide feasible 3D printers and databases for individuals to print customised items. The market-driven configuration could also help to produce customised prototypes for industrial players. As one R\&D manager highlighted, why a customer stays with the firm is because 'customers want to print their personal favourite designs or items designed by themselves via the use of our software'.

\subsubsection{Co-evolved Design Capability}


In each of these three cases, the design capability of one stakeholder is dependent on the other stakeholders and evolves alongside the development and evolution of others' design capabilities. Hence, we coded this as co-evolved design capability. In the market-driven case, firms and organisations enhance their design abilities through quickly testing the feasibility of conceptual products and identifying the design flaws of prototypes. In the individual-driven case, TierTime contributes to enhancing individuals' design capability and creativity by providing feasible 3D printers at low cost. Large software companies have also established platforms for customers to provide and share data, gradually forming an open-source data community. In this circumstance, the complementor's role is very important to not only the evolution of the technology but also the evolution of the manufacturing system. Relationships with the complementors should be well managed to ensure evolutionary robustness (Teece 2011).

\section{Conclusion}

This paper reports research on the evolution of manufacturing systems and the elements of manufacturing strategies in the context of an emerging technology (3D printing). It makes several theoretical contributions to the field of $\mathrm{OM}$ and provides management implications for practitioners.

\subsection{Theoretical Contributions}

First, this research has contributed to $\mathrm{OM}$ in terms of adopting a business ecosystem perspective from which to investigate manufacturing systems/strategies, rather than from a firm or network view. This is believed to bring a comprehensive understanding of the complex nature of the manufacturing systems in the context of 3D printing. Previous research on the manufacturing system and its strategies has mainly focused on the firm level (Hayes and 
Wheelwright 1984) or the network level (Shi and Gregory 1998; Srai and Gregory 2008). In line with Baldwin's (2012) argument that it is no longer sufficient to observe a complex system from a firm view, this research has put the study into a broader and more complex context: a business ecosystem consisting of various stakeholders playing different roles.

Second, in addition to those traditional elements, this research identified functional role, platform and solution as three key elements of the strategic choices of an ecosystem-based manufacturing system. The understandings of those functional roles reflect the perspective of extended RBV (Lavie 2006) to look at various stakeholders from external but collaborating and co-evolving around the platform to offer diverse solutions (products/service) to consumers. Furthermore, with the emphasis on the collaboration between constructive elements and processes, this research identified two key dimensions (platform openness and solution diversity) to classify an ecosystem-based manufacturing system, which are different from the two dimensions (products and processes) used to categorise firm-based manufacturing systems (Hayes and Wheelwright 1984) and the two dimensions (geographic dispersion and manufacturing coordination) used to classify international manufacturing networks (Shi and Gregory 1998). We have summarised this evolution of the manufacturing system (from firm based to network based and then to ecosystem based) in Figure 5.

Third, the results provide a framework for classifying ecosystem-based manufacturing systems in the context of emerging technologies into three categories: government-driven, market-driven and individual-driven configurations. This helps us to fully understand the development of a manufacturing system in the context of emerging technologies like 3D printing. Moreover, following neo-institutional theory (Suddaby, Seidl and Lê 2013), better understanding of different classifications can help us to better construct the system, which in return will encourage organisations to put more efforts into converging structures and processes. 


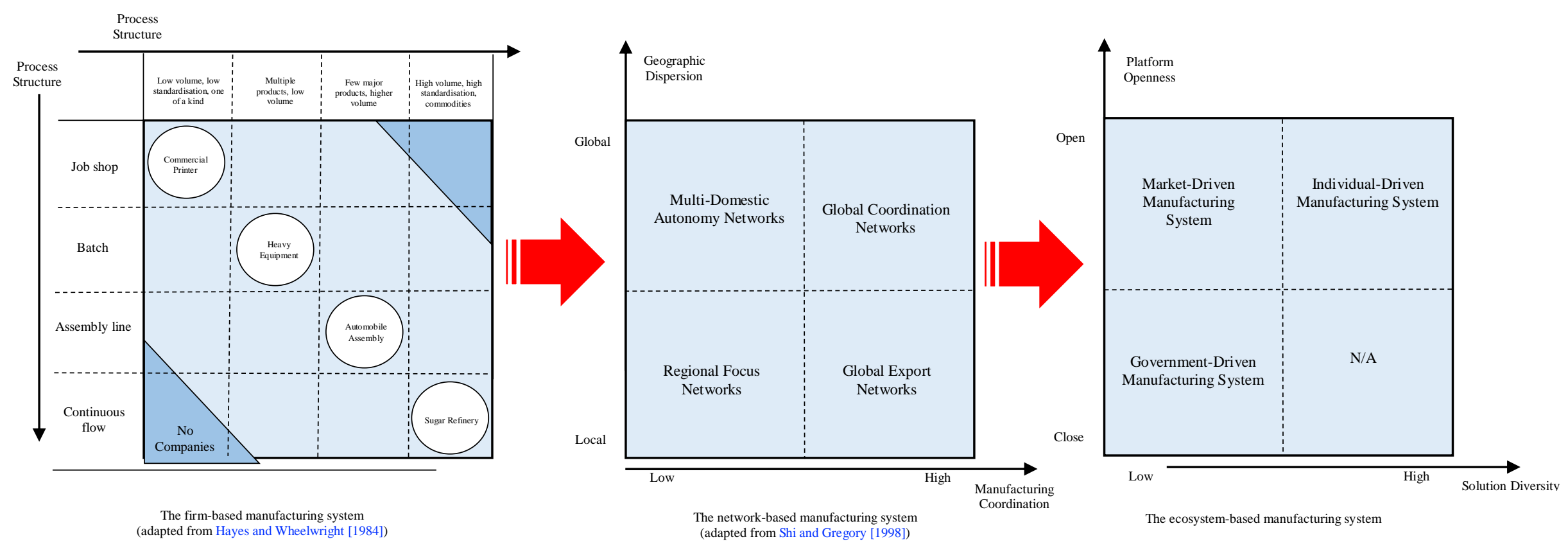

Figure 5. Evolution of the manufacturing system: from firm based to network based and then to ecosystem based 
Fourth, the research results show that the different classifications of manufacturing systems need different capabilities to accommodate them. Based on previous research (Hayes and Wheelwright 1984; Shi and Gregory 1998), the results highlight the four manufacturing capabilities as collaborative manufacturing flexibility, rapid thriftiness ability, selfcustomisation and co-evolved design capability, which is additional capabilities identified on ecosystem level comparing those elements on firm/network levels. These capability elements reflect the key points of dynamic capability that it helps to integrate internal and external resources to mitigate uncertainties in a fast-changing environment (Teece and Leih, 2016) such as the context of $3 \mathrm{D}$ printing. The research results also reveal an evolution of capabilities from firm-based and network-based manufacturing systems to ecosystem-based manufacturing systems, as described in Figure 5.

\subsection{Management Implications}

The research findings also provide practical guidance for industrial practitioners (the leaders in the focal organisations and the complementors) and policymakers when they are considering the development and operations management of emerging industries.

The results highlight that operations managers can consider the bigger picture of their business from the perspective of the business ecosystem, rather than the usual focus on the firm or the network; they also provide the insight for managers that competing against a different business ecosystem can be more important than competing against firms. The two identified elements of platform and solution for strategic choices encourage managers to consider the overall outcome from the business ecosystem, rather than from individual firms. In other words, this means considering platform competition and network effects, as well as providing a more open platform to attract more partners and consumers simultaneously. Furthermore, the identified functional roles (as in Figure 3) and classification of manufacturing system (as in 
Figure 4), will help managers and entrepreneurs to better position themselves in the rapid changing environment. Meanwhile, the summarised evolution map of manufacturing system (as in Figure 5), it provides firm owners a way of deriving appropriate strategy for their sustainable development especially in a fast-changing environment with emerging technologies like 3D printing.

The research results provide managers with a comprehensive understanding of what kinds of manufacturing capabilities their businesses need to acquire from the perspective of the business ecosystem. No matter whether the firm is the focal firm or one of the complementors, all firms in the ecosystem need to understand the importance of collaboration and will need to work closely to achieve successful co-evolution in the ecosystem, in particular in the context of emerging technologies. Furthermore, the research results suggest that it is better to cooperate with ecosystem stakeholders at the early stage of adopting and implementing an emerging technology.

In terms of policymakers in emerging economies, it would be better to view emerging industries from the business ecosystem perspective. They could easily obtain general information about the maturity level of an industry and then determine whether a government agency should play the focal role or just be a complementor to the other focal roles within the business ecosystem. The results also highlight the important role of university research labs in developing and commercialising emerging technologies. Additionally, policymakers could highlight potential capability development paths to different stakeholders to guide their entry into emerging industries, like 3D printing. The research results could guide the further development of business ecosystem-based manufacturing systems and could guide the nurturing of new industries with emerging technologies. 


\subsection{Limitations and Future Research}

This paper has addressed the strategic choices and manufacturing capabilities of the ecosystem-based manufacturing system in the context of emerging technologies. However, it has not touched upon best practices due to the emergent nature of emerging technologies like 3D printing. It is suggested that future research should conduct historic and comparative studies to identify the best practices of ecosystem-based manufacturing systems when adopting and implementing emerging technologies.

Another limitation of this research was that it did not quantitatively measure platform openness and solution diversity. It is important for future research to develop a scale to measure these aspects and to measure the relationship between manufacturing capabilities and strategic choices. Meanwhile, further research could verify the classification proposed in Figure 4. This could provide further evidence to see whether the empty area could be filled. Furthermore, this could be linked with the performance perspective to identify how different classifications and manufacturing capabilities can influence the performance of both the whole ecosystem-based manufacturing system and the individual stakeholders within it.

This research selected 3D printing technology as the research context; the findings including strategic choices and manufacturing capabilities are only relevant with the 3D printing context. Hence the findings could be further tested if expanding the case scope to other emerging technologies, like electric vehicles, mobile computing and solar cells. This would be helpful to explore, verify and refine the research results from this study to contribute to the fuller understanding of the ecosystem-based manufacturing system. Meanwhile, as this research was conducted in the Chinese market, future research could be expanded to other economies to compare and refine the research results. 


\section{References}

Achillas, C., D. Tzetzis and M. O. Raimondo. 2017. "Alternative Production Strategies Based on the Comparison of Additive and Traditional Manufacturing Technologies." International Journal of Production Research 55 (12): 3497-3509.

Ambrosini, V., C. Bowman and N. Collier 2009. "Dynamic Capabilities: An Exploration of How Firms Renew Their Resource Base.” British Journal of Management 20 (s1): S9S24.

Anderson, P. and C. A. Sherman. 2007. "A Discussion of New Business Models for 3D Printing." International Journal of Technology Marketing 2 (3): 280-294.

Arya, B. and Z. Lin. 2007. "Understanding Collaboration Outcomes from an Extended Resource-Based View Perspective: The Roles of Organizational Characteristics, Partner Attributes, and Network Structures.” Journal of Management 33 (5): 697-723.

Auerbach, C. F. and L. B. Silverstein. 2003. Qualitative Data: An Introduction to Coding and Analysis. New York: NYU Press.

Avella, L., D. Vazquez-Bustelo and E. Fernandez. 2011. "Cumulative Manufacturing Capabilities: An Extended Model and New Empirical Evidence.” International Journal of Production Research 49 (3): 707-729.

Baldwin, C. Y. 2012. "Organization Design for Business Ecosystems." Journal of Organization Design 1 (1): 20-23.

Barney, J., M. Wright and D. J. Ketchen. 2001. "The Resource-Based View of the Firm: Ten Years After 1991." Journal of Management 27 (6): 625-642.

Baumers, M., L. Beltrametti, A. Gasparre and R. Hague. 2017. "Informing Additive Manufacturing Technology Adoption: Total Cost and the Impact of Capacity Utilisation.” International Journal of Production Research 55 (23): 6957-6970.

Berman, B. 2012. “3-D printing: The new industrial revolution”, Business Horizons, Vol. 55 No. 2, pp. 155-162.

Boyer, K. K. and M. W. Lewis. 2002. "Competitive Priorities: Investigating the Need for Trade-Offs in Operations Strategy.” Production and Operations Management 11 (1): 9-20.

Chatha, K. A. and I. Butt. 2015. "Themes of Study in Manufacturing Strategy Literature." International Journal of Operations \& Production Management 35 (4): 604-698.

Chesbrough, H. W. 2005. Open Innovation: The New Imperative for Creating and Profiting from Technology. Boston: Harvard Business School Press. 
Choi, T. and S. Guo. 2017. "Responsive Supply in Fashion Mass Customisation Systems with Consumer Returns.” International Journal of Production Research in press: 1-14. doi:10.1080/00207543.2017.1292065.

Choudhari, S., G. Adil and U. Ananthakumar. 2012. "Choices in Manufacturing Strategy Decision Areas in Batch Production System - Six Case Studies.” International Journal of Production Research 50 (4): 3698-3717.

Colotla, I., Y. Shi and M. J. Gregory. 2003. "Operation and Performance of International Manufacturing Networks." International Journal of Operations \& Production Management 23 (10): 1184-1206.

Corbett, L. 2008. "Manufacturing Strategy, the Business Environment, and Operations Performance in Small Low-Tech Firms." International Journal of Production Research 46 (20): 5491-5513.

Corbett, L. and G. Claridge. 2002. "Key Manufacturing Capability Elements and Business Performance.” International Journal of Production Research 40 (1): 5109-5131.

Danneels, E. 2002. "The Dynamics of Product Innovation and Firm Competences." Strategic Management Journal 23 (12): 1095-1121.

Day, G. S. and P. J. Schoemaker. 2000. "Avoiding the Pitfalls of Emerging Technologies." California Management Review 42 (2): 8-33.

DiMaggio, P. and W. W. Powell. 1983. “The Iron Cage Revisited: Collective Rationality and Institutional Isomorphism in Organizational Fields.” American Sociological Review 48 (2): $147-160$.

Eisenhardt, K. M. and C. B. Schoonhoven. 1996. "Resource-based view of strategic alliance formation: Strategic and social effects in entrepreneurial firms." Organization Science 7 (2): 103-209.

Eisenhardt, K. M. and M. E. Graebner. 2007. “Theory Building from Cases: Opportunities and Challenges." Academy of Management Journal 50 (1): 25-32.

Feldmann, A., J. Olhager, D. Fleet and Y. Shi. 2013. "Linking Networks and Plant Roles: The Impact of Changing a Plant Role." International Journal of Production Research 51 (19): 5696-5710.

Gardan, J. 2016. "Additive Manufacturing Technologies: Stat of the Art and Trends." International Journal of Production Research 54 (10): 3118-3132.

Garrido, E. D., M. L. Martín-Peña and F. García-Muiña. 2007. "Structural and Infrastructural Practices as Elements of Content Operations Strategy. The Effect on a Firm's Competitiveness.” International Journal of Production Research 45 (9): 2119-2140. 
Gawer, A. and M. A. Cusumano. 2014. "Industry Platforms and Ecosystem Innovation." Journal of Product Innovation Management 31 (3): 417-433.

Gibbert, M., W. Ruigrok and B. Wicki. 2008. "What Passes as a Rigorous Case Study?" Strategic Management Journal 29 (13): 1465-1474.

Hämäläinen, M. and A. Ojala 2015. “Additive Manufacturing Technology: Identifying Value Potential in Additive Manufacturing Stakeholder Groups and Business Networks." AMCIS 2015: Proceedings of the Twenty-First Americas Conference on Information Systems. http://aisel.aisnet.org/amcis2015/EndUser/GeneralPresentations/1/.

Hayes, R. H. and S. C. Wheelwright. 1984. Restoring Our Competitive Edge: Competing Through Manufacturing. New York: John Wiley \& Sons Inc.

Helfat, C. E. and M. A. Peteraf. 2003. "The Dynamic Resource-Based View: Capability Lifecycles.” Strategic Management Journal 24 (10): 997-1010.

Iansiti, M. and R. Levien. 2004a. "Strategy as Ecology.” Harvard Business Review 82 (3): 6881.

Iansiti, M. and R. Levien. 2004b. Keystones and Dominators: Framing Operating and Technology Strategy in a Business Ecosystem. Boston: Harvard Business School.

Iansiti, M. and R. Levien. 2004c. The Keystone Advantage: What the New Dynamics of Business Ecosystems Mean for Strategy, Innovation, and Sustainability. Boston: Harvard Business School Press.

Jaehne, D. M., M. Li, R. Riedel and E. Mueller. 2009. "Configuring and Operating Global Production Networks.” International Journal of Production Research 47 (8): 20132030.

Jain, A., P. K. Jain, F. T. S. Chan and S. Singh. 2013. “A Review on Manufacturing Flexibility.” International Journal of Production Research 51 (9): 5946-5970.

Lavie, D. 2006. "The competitive advantage of interconnected firms: an extension of the resource-based view." The Academy of Management Review 31 (3): 638-658.

Li, Y., G.Z. Jia, Y. Cheng, and Y.C. Hu. 2017. "Additive Manufacturing Technology in Spare Parts Supply Chain: A Comparative Study.” International Journal of Production Research 54 (5): 1498-1515.

Long, Y. G., J. Y. Pan, Q. H. Zhang and Y. J. Hao. 2017. “3D Printing Technology and Its Impact on Chinese Manufacturing." International Journal of Production Research 55 (5): 1488-1497. 
McAdam, R., U. Bitici and B. Galbraith, 2017. “Technology Alignment and Business Strategy: A Performance Measurement and Dynamic Capability Perspective." International Journal of Production Research 55 (23): 7168-7186.

Miltenburg, J. 2005. Manufacturing Strategy - How to Formulate and Implement a Winning Plan. Portland, OR: Productivity Press.

Miltenburg, J. 2009. "Setting Manufacturing Strategy for a Company's International Manufacturing Network.” International Journal of Production Research 47 (22): 6179-6203.

Moore, J. 1993. "Predators and Prey: A New Ecology of Competition." Harvard Business Review 71 (3): 75-86.

Moore, J. F. 1996. The Death of Competition: Leadership and Strategy in the Age of Business Ecosystems. New York: Harper Business.

Moore, J. F. 1998. “The Rise of a New Corporate Form.” Washington Quarterly 21 (1): 167181.

Moore, J. F. 2006. "Business Ecosystems and the View from the Firm." Antitrust Bulletin 51 (1): $31-75$.

Niaki, M. K. and F. Nonino. 2017. "Additive Manufacturing Management: A Review and Future Research Agenda.” International Journal of Production Research 55 (5): 14191439.

Olhager, J. and A. Feldmann. 2017. "Distribution of Manufacturing Strategy Decision-Making in Multi-Plant Networks." International Journal of Production Research in press: 117. doi:10.1080/00207543.2017.1401749.

Oliff, M.D., Arpan, J.S. and DuBois, F. 1989. "Global manufacturing rationalization: the design and management of international factory networks", In Ferdow, K. (Ed.), Managing International Manufacturing, Elsevier, Amsterdam, pp. 41-65.

Paquet, M., A. Martel and B. Montreuil. 2008. “A Manufacturing Network Design Model Based on Processor and Worker Capabilities." International Journal of Production Research 46 (7): 2009-2030.

Pérez Pérez, M., A. M. Serrano Bedia and M. C. López Fernández. 2016. “A Review of Manufacturing Flexibility: Systematising the Concept." International Journal of Production Research 54 (10): 3133-3148.

Priem, R. L. and J. E. Butler. 2001. 'Is the Resource-Based 'View' a Useful Perspective for Strategic Management Research?” Academy of Management Review 26 (1): 22-40. 
Rong, K., G. Hu, Y. Lin, Y. Shi and L. Guo. 2015. “Understanding Business Ecosystem Using a 6C Framework in Internet-of-Things-Based Sectors." International Journal of Production Economics 159: 41-55.

Rong, K. and Y. Shi. 2014. Business Ecosystems: Constructs, Configurations, and the Nurturing Process. Hampshire: Palgrave Macmillan.

Rong, K., Y. Shi and J. Yu. 2013. "Nurturing Business Ecosystems to Deal with Industry Uncertainties." Industrial Management \& Data Systems 113 (3): 385-402.

Rudberg, M. and B. Martin West. 2008. "Global Operations Strategy: Coordinating Manufacturing Networks.” Omega 36 (1): 91-106.

Sarmiento, R., J. Sarkis and M. Byrne. 2010. "Manufacturing Capabilities and Performance: A Critical Analysis and Review.” International Journal of Production Research 48 (5): 1267-1286.

Scott, W. R. 2013. Institutions and Organizations: Ideas, Interests, and Identities. London: Sage Publications.

Shang, T., F. Chang and Y. Shi. 2012. "Deciphering Business Ecosystem Capabilities of the Emerging Electric Vehicle Industry." Proceedings of the IEEE International Conference on Industrial Engineering and Engineering Management, 638-642.

Shi, G., J. Baldwin, S. C. Lenny Koh and T. C. Choi. 2017. "Fragmented Institutional Fields and Their Impact on Manufacturing Environmental Practices." International Journal of Production Research in press: 1-16. doi:10.1080/00207543.2017.1353712.

Shi, Y. 2003. "Internationalisation and Evolution of Manufacturing Systems: Classic Process Models, New Industrial Issues, and Academic Challenges.” Integrated Manufacturing Systems 14 (4): 357-368.

Shi, Y. 2004. “A Roadmap of Manufacturing System Evolution.” In Evolution of Supply Chain Management, edited by Y. S. Chang, H. C. Makatsoris and H. D. Richards, 341-365. New York: Springer US.

Shi, Y. and M. Gregory. 1998. "International Manufacturing Networks-To Develop Global Competitive Capabilities.” Journal of Operations Management 16 (2): 195-214.

Shi, Y., M. Gregory and M. Naylor. 1997. "International Manufacturing Configuration Map: A Self-Assessment Tool of International Manufacturing Capabilities.” Integrated Manufacturing Systems 8 (5): 273-282.

Skinner, W. 1974. "The focused factory", Harvard Business Review 52 : 113-121. 
Siggelkow, N. 2002. “Evolution Toward Fit.” Administrative Science Quarterly 47 (1): 125159.

Srai, J. S. and M. Gregory. 2008. "A Supply Network Configuration Perspective on International Supply Chain Development." International Journal of Operations \& Production Management 28 (5): 386-411.

Strauss, A. and J. M. Corbin. 1997. Grounded Theory in Practice. Sage Publications. http://books.google.co.uk/books?hl=en\&lr=\&id=TtRMolAapBYC\&oi=fnd\&pg=PR7 $\& \mathrm{dq}=$ Strauss + and + Corbin\&ots=DycqartLYo\&sig=0B1KAXQh0KZYlnA3ZsGDNeK kCTY.

Suddaby, R., D. Seidl and J. K. Lê. 2013. "Strategy-as-Practice Meets Neo-Institutional Theory." Strategic Organization 11 (3): 329-344.

Teece, D. J. 2007. "Explicating Dynamic Capabilities: The Nature and Microfoundations of (Sustainable) Enterprise Performance.” Strategic Management Journal 28 (13): 13191350.

Teece, D. J. 2011. "Dynamic Capabilities: A guide for Managers." Ivey Business Journal 75 (2): 29-32.

Teece, D. J. 2018. "Business Models and Dynamic Capabilities.” Long Range Planning 51 (1): 40-49.

Teece, D. J. and G. Pisano. 1994. "The Dynamic Capabilities of Firms: An Introduction." Industrial and Corporate Change 3 (3): 537-556.

Teece, D. J. and S. Leih. 2016. "Uncertainty, innovation, and dynamic capabilities: An introduction." California Management Review 58 (4): 5-12.

Voss, C. A. 2005. "Paradigms of Manufacturing Strategy Re-Visited." International Journal of Operations \& Production Management 25 (12): 1223-1227.

Wang, Q. F., X. Xun, S. Cobb, G. Lawson and S. Sharples. 2016. “3D Printing System: An Innovation for Small-Scale Manufacturing in Home Settings? - Early Adopters of 3D Printing Systems in China." International Journal of Production Research 54 (20): 6017-6032.

Ward, P. T., D. J. Bickford and G. K. Leong, 1996. "Configurations of Manufacturing Strategy, Business Strategy, Environment and Structure.” Journal of Management 22 (4): 597626.

Yin, R. 2014. Case Study Research: Design and Methods. 5th ed. London: Sage Publishing. 
Zahra, S. A., H. J. Sapienza and P. Davidsson. 2006. "Entrepreneurship and Dynamic Capabilities: A Review, Model and Research Agenda." Journal of Management Studies 43 (4): 917-955.

Zhang, W., Y. J. Shi., M. Y. Yang, X. J. Gu, R. Z. Tang and X. H. Pan. 2017. "Ecosystem evolution mechanism of manufacturing service system driven by service providers." International Journal of Production Research 55 (12): 3542-3568. 